\title{
PENGEMBANGAN MODAL SOSIAL MASYARAKAT DALAM MUWUJUDKAN PROGRAM MAKASSAR TIDAK RANTASA
}

\author{
Oleh: Hamsah', Sopian Tamrin², Mansyur Achmad ${ }^{3}$ \\ ${ }^{1}$ Universitas Azzahra \\ ${ }^{2}$ Universitas Negeri Makassar \\ ${ }^{3}$ Institut Pemerintahan Dalam Negeri
}

\begin{abstract}
Abstrak
Program Makassar tidak Rantasa sebagai suatu inovasi dan solusi dalam menangani permasalahan kebersihan yang ada yang ada di Kota Makassar. Tujuan dari penelitian ini adalah untuk mengetahui nilai-nilai modal sosial masyarakat di Kecamatan Mariso dalam mendukung program Makassar tidak rantasa. Metode dalam penelitian ini adalah kualitatif dengan pendekatan studi kasus. Proses pengumpulan data dengan teknik wawancara, observasi dan studi dokumentasi. Data diperoleh dari informan yang terdiri dari unsur pemerintah kota, kecamatan, keluarahan, agen pembaharu tokoh masyarakat dan masyarakat biasa. Hasil penelitian menujukkan modal sosial masyarakat dalam program tersebut dengan partisipasi mereka dalam kegiatan bergotong-royong dalam menjaga kebersihan dan senantiasa berpegang pada nilai-nilai sipakatu (Saling memanusiakan), sipakainge (Saling mengingatkan) dan sipakalebbi (Saling menghargai).
\end{abstract}

Kata Kunci: Agen Pembaharu, Makassar Tidak Rantasa, Modal Sosial.

\section{PENDAHULUAN}

Penataan kota dari aspek kebersihan merupakan isu nasional yang tidak kunjung selesai di setiap kota di Indonesia. Penyebabnya adalah tingkat populasi penduduk yang semakin tinggi ditambah dengan tingkat kepedulian masyarakat yang lemah dalam menjaga kebersihan, seperti membuang sampah pada tempatnya, bangunan dan fasilitas kota yang tidak teratur, begitu pula dengan bertambahnya sampah visual (baliho, iklan produk, iklan politik, dan seterusnya). Permasalahan kota dari aspek kebersihan juga dipengarhi oleh karakter atau perilaku masyarakat yang beragam sehingga hal ini menarik untuk ditinjau secara holistik. Perilaku masyarakat Makassar yang relatif tidak peduli dalam menyikapi masalah kebersihan erat kaitannya dengan sistem kebudayaan (pendidikan atau pengetahuan, system kelembagaan, industri, agama, estetika, system ekonomi dan seterusnya).

Program Makassar tidak Rantasa sebagai bentuk solusi untuk menangani permasalahan kebersihan yang ada. Sekaligus program tersebut menjadi harapan dan filosofi Makassar yang memegang prinsip siri' (malu) dalam hal ini Makassar akan malu ketika terlihat jorok atau sembraut dalam penataannya. Persoalan rantasa bukan hanya pada persoalan kebersihan semata, tetapi juga pada pola pikir dan perilaku masyarakat.

Kesuksesan program Makassar tidak rantasa tidak cukup hanya dengan mengandalkan modal materi atau ekonomi semata. Tetapi juga dibutuhkan modal-modal yang lain. Modal yang dimaksud adalah modal sosial dari masyarakat. Modal sosial (social capital) adalah salah satu faktor penting yang menentukan sebuah program 
dapat berjalan dengan baik. Peranan modal sosial, tidak kalah pentingnya dengan infrastruktur lainnya, sehingga upaya untuk membangun modal sosial perlu diprioritaskan demi kesuksesan program Makassar tidak Rantasa. Pembentukan modal sosial dapat mempercepat dalam merealisasi sebuah program dengan adanya jaringan (networks), norma (norms), dan kepercayaan (trust) di dalamnya yang menjadi kolaborasi (koordinasi dan kooperasi) sosial untuk kepentingan bersama.

Modal sosial merupakan aset yang terbangun dan tumbuh disetiap diri individu sebagai hasil dari hubungan bermasyarakat yang baik. Modal sosial memiliki beragam pengertian dari para ahli namun pada substasinya adalah sama. Fukuyama (2014) mengungkapkan bahwa modal sosial secara sederhana bisa didefinisikan sebagai rangkaian nilai-nilai atau norma-norma informal yang dimiliki bersama di antara para anggota suatu kelompok masyarakat yang memungkinkan terjalinnya kerja sama di antara mereka. Selanjutnya Fukuyama (dalam Maulana, 2009) menjelaskan bahwa social capital can be defined simply as the existence of a certain set of informal values or norms shared among members of a group that permit cooperation among themi. Modal sosial adalah serangkaian nilai-nilai atau norma-norma informal yang dimiliki bersama diantara para anggota suatu kelompok masyarakat yang memungkinkan terjalinnya kerja sama di antara mereka. Selanjutnya menurut Putnam (dalam Field, 2014) bahwa modal sosial merujuk pada bagian dari organisasi sosial seperti kepercayaan, norma dan jaringan, yang dapat meningkatkan efesiensi masyarakat dengan memfasilitasi tindakan-tindakan terkoordinasi. Hanifan (dalam Aldrich, 2015) modal sosial diidentifikasikan sebagai hubungan baik, kerja sama, saling simpati, dan hubungan sosial di antara sekelompok individu dan keluarga yang membentuk sebuah unit sosial

Selanjutnya menurut Scheiber (2014) modal sosial adalah tentang solidaritas, kepercayaan diri berasal dari hubungan sosial yang melibatkan keluarga, teman, rekan kerja dan lain-lain. Kemudian Oxoby (2009) mengemukakan bahwa modal sosial adalah sebuah pengorbana individu berupa waktu dan tenaga dalam upaya untuk meningkatkan kerja sama dengan orang lain. Hal demikian juga diungkapkan oleh Chang (2009) dan Bourdieu (dalam Shen, 2015) modal sosial sebagai tingkat agregat yang umumnya diartikan sebagai kekuatan organisasi sosial seperti adanya kepercayaan, norma dan jaringan yang dapat meningkatkan efisiensi dari masyarakat untuk memfasilitasi tindakan yang terkoordinasi. Berdasarkan uraian di atas, maka salah satu tujuan dari penelitian ini adalah untuk mengetahui nilai-nilai modal sosial masyarakat di Kecamatan Mariso dalam mendukung program Makassar tidak rantasa.

\section{METODE PENELITIAN}

Metode dalam penelitian ini menggunakan metode kualitatif dengan pendekatan studi kasus. Syaodih (2007) penelitian kualitatif sebagai suatu penelitian yang ditujukan untuk mendeskripsikan dan menganalisis fenomena, peristiwa, aktivitas sosial, sikap kepercayan, persepsi, pemikiran orang secara individu maupun kelompok. Pemilihan pendekatan metode tersebut didasarkan atas pertimbangan 
data yang diperoleh sangat mendalam, tidak dapat di kuantitatifkan karena hal yang dikaji berupa modal sosial masyarakat setempat. Proses pengumpulan data dengan teknik wawancara mendalam, observasi dan studi dokumentasi. Lokasi Penelitian ini adalah Kecamatan Mariso Kota Makassar yang dengan 18 imforman (unsur pemerintah kota, kecamatan, kelurahan, tokoh masyarakat dan masyarakat biasa). Pemilihan lokasi tersebut sebagai lokasi penelitian karena kecamatan Mariso menjadi fokus dari program pemerintah tentang Makassar tidak rantasa.

\section{PEMBAHASAN}

Modal sosial masyarakat dapat diamati melalui kebiasaan/perilku positif yang dimiliki masyarakat Mariso seperti semangat pergaulan yang rukun dan kental dengan nuansa kekeluargaan yang akrab, nilai-nilai toleransi, musyawarah maupun kebiasaan/prilaku positif yang tertanam melalui organisasi formal maupun organisasi informal dari masyarakat Mariso. Modal sosial diidentifikasikan sebagai hubungan baik, kerja sama, saling simpati, dan hubungan sosial di antara sekelompok individu dan keluarga yang membentuk sebuah unit sosial. Hal ini juga sangat terlihat dalam keidupan masyarakat Mariso dalam hal mendukung program Makassar tidak rantasa.

Hasil penelitian menunjukkan bahwa berbagai kebiasaan dan prilaku yang dimiliki masyarakat Mariso memiliki prekuensi pelaksanaan yang rutin. Sebagai contoh kegiatan kerja bakti untuk kebersihan lingkungan yang berjalan dalam dua kali seminggu melalui kegiatan jumat bersih dan kerja bakti mingguan yang dilakukan secara giliran di lingkup Kecamatan Mariso. Mengenai kebiasaan dan prilaku, dilokasi penelitian pada umumnya masih memiliki kebersamaan yang tinggi. Salah satu kebiasaan yang dilaksanakan dalam kehidupan bertetangga adalah melaksanakan kerja bakti untuk membersihkan saluran, pemeliharaan lingkungan, tempat ibadah dan fasilitas umum lainnya yang setelah itu diakhiri dengan makan bersama. Kegiatan bersama seperti ini dapat menjadi modal utama dalam peningkatan peran serta penduduk dalam mengelola dan menjaga prasarana yang ada di lingkungannya.

Keakraban antara pemerintah kelurahan dengan masyarakat menjadi sarana perekat hubungan diantara mereka sehingga program-program pemerintah yang menuntut keterlibatan warga masyarakat, warga ikut berperan serta tanpa merasa terpaksa. Walaupun tidak bisa dipungkiri, wilayah ini juga tidak terlepas dari kehidupan kota yang cenderung individualistis. Sifat seperti ini timbul karena tuntunan ekonomi untuk bekerja.

Berdasarkan hasil penelitian yang dilakukan peneliti di Kecamatan Mariso dapat diuraikan bahwa masyarakat Mariso memanfaatkan beragam model sosial dalam melaksanakan program Masyarakat Tidak Rantasa. Model sosial tersebut sebagaimana yang dijelaskan oleh Fukuyama (2014) bahwa modal sosial secara sederhana bisa didefinisikan sebagai rangkaian nilai-nilai atau norma-norma informal yang dimiliki bersama di antara para anggota suatu kelompok masyarakat yang memungkinkan terjalinnya kerja sama di antara mereka. 
Lebih lanjut, modal sosial masyarakat mariso juga tampak dalam praktekpraktek pelaksanaan program Makassar Tidak Rantasa sebagaimana yang dikemukakan oleh Putnam (dalam Field, 2014) bahwa modal sosial merujuk pada bagian dari organisasi sosial seperti kepercayaan, norma dan jaringan, yang dapat meningkatkan efesiensi masyarakat dengan memfasilitasi tindakan-tindakan terkoordinasi. Selanjutnya pada tahun 1990 Putnam kembali memberikan penegasan tentang modal sosial (Putnam, 1996) yaitu: Modal sosial adalah bagian dari kehidupan sosial yang terdiri dari kepercayaan, norma dan jaringan yang mendorong partisipasi bertindak bersama lebih efektif untuk mencapai tujuan-tujuan bersama. Berdasarkan ketiga poin modal sosial yang telah dirumuskan oleh kedua tokoh itu pula, modal sosial masyarakat Mariso dapat dianalisa terkait dengan pelaksanaan program Makassar Tidak Rantasa. Hal tersebut dapat dipaparkan sebagai berikut:

\section{Kepercayaan}

Dari hasil penelitian yang dilakukan, menunjukan bahwa masyarakat Mariso memiliki hubungan yang dibangun atas dasar kepercayaan yang kuat di dalamnya ditopang oleh sikap kejujuran, sikap saling menghargai dan keterbukan sesama mereka. Saling percaya (jujur, terbuka, dan menghargai) dari hasil wawancara dengan informan, bahwa sikap tersebut merupakan suatu halyang sangat penting dalam masyarakat untuk membangun hubungan agardapat menopang dalam program Makassar tidak rantasa.

Masyarakat Mariso tumbuh dalam masyarakat yang harmonis di bawah pemerintah dan koordinasi antara camat, lurah, RT, RW dan tokoh-tokoh masyarakat yang berpengaruh. Koordinasi tersebut dilakukan untuk memperkuat sistem informasi dan dukungan kerjasama setiap program pemerintah terhadap masyarakat, sehingga kepercayaan antara pemerintah, tokoh masyarakat dan masyarakat biasa tetap terjaga. Implementasi modal sosial ini terwujud dalam salah satu program pemerintah yang menjadi fokus penelitian peneliti, yakni terkait pelaksanaan program Masyarakat Tidak Rantasa.

Pelaksanaan program Makassar Tidak Rantasa ini pula melibatkan seluruh masyarakat di kecamatan Mariso tanpa membeda-bedakan status dan agama. Adapun masyarakat yang masih enggan untuk membersihkan dan mengumpulkan sampahnya, maka dengan kemurahan hati masyarakat yang lain akan mengingatkan dan membantu untuk membersihkan agar tergerak kesadarannya untuk turut serta melakukan program tersebut. Dalam hal ini, kelancaranprogram Makassar Tidak Rantasa juga didorong oleh sikap toleransi (tolerance) dan kemurahan hati (generosity) masyarakatnya untuk terus saling mengayomi. Tindakan demikian, secara tidak langsung memperkuat bangunan kepercayaan antara anggota masyarakat bahwa program tersebut benar-benar bermanfaat bagi kehidupan mereka sebagai anggota masyarakat di kecamatan Mariso.

\section{Nilai dan Norma}

Sehubungan dengan nilai dan norma dalam pelaksanaan program Makassar Tidak Rantasa, masyarakat memegang utuh nilai warisan budaya yang masih berakar 
kuat dalam kehidupan masyarakat.Sebagaimana yang diungkapkan oleh Monika (2013) bahwa warisan budaya biasanya termasuk dalam diskusi umum tentang pembangunan modal social. Karena modal sosial dan warisan budaya memiliki bentuk kesamaan dimana kebanyakan warisan budaya yang mengajarkan tentang aspek kejujuran, kebersamaan dan lain-lain. Sehingga banyak diantara peneliti yang menggabungkan atau menjadikan warisan budaya sebagai suatu yang bisa menopang terbangunnya modal sosial dalam kehidupan masyarakat.

Sebagaimana dengan yang diungkapkan oleh salah satu informan yang menyatakan bahwa di dalam masyarakat Makassar khususnya keamatan Mariso memiliki nilai yang dipegang teguh dan menopang dalam pelaksanaan program Makassar tidak rantasa yakni nilai Sipakatau, sipakainge, dan sipakalebbi. Nilai Sipakatau artinya kita selaku warga Makassar senantiasa saling menghargai, memanusiakan satu sama lain dan tidak ada pemisah antara kita, baik itu pejabat, atasan maupun masyarakat biasa. Semua sama-sama manusia yang perlu untuk dimanusiakan. Sipakainge, artinya yaitu saling mengingatkan satu sama lain, karena kita ini adalah makhluk tuhan yang penuh dengan keterbatasan yang butuh saling mengingatkan ketika saat kita lupa. Sipakalebbi, artinya saling menghargai, saling mengangkat, dan mengayomi. Jadi, selaku pemerintah dan masyarakat tidak ada pemisah dan bersatu dalam ikatan masyarakat yang sama-sama menjalankan fungsinya masing-masing untuk menegakkan nilai-nilai kemanusiaan. Nilai budaya tersebut menjadi poin penting dalam menggerakkan kebersamaan masyarakat untuk bergandengan tangan mewujudkan program pemerintah, khususnya yang menjadi perhatian serius yaitu masalah kebersihan lingkungan dan penataan tatakota.

\section{Jaringan}

Pelaksanaan program Makassar Tidak Rantasa tentu tidak lepas dari partisipasi masyarakat, jajaran pemerintah, dan tentunya melibatkan beberapa lembaga formal maupun non formal. Di kecamatan ini setidaknya telah beberapa kali melakukan kerjasama (cooperation) dengan lembaga-lembaga lain, yakni Badan Keswadan Masyarakat, Badan Pemberdayaan Perempuan, Kualisi Perempuan Indonesia, PKK, BKL, $\mathrm{BKR}$, dan BKB. Kerjasama tersebut dilakukan untuk mendapatkan dukungan moril dan materil terhadap kelancaran pelaksanaan program dan memperkuat solidaritas antara sesama masyarakat dan pemerintah serta lembaga-lembaga non formal yang bergerak dalam pembangunan sumber daya masyarakat.

Modal sosial ini juga tampak dari partisipasi masyarakat dalam melaksanakan program Makassar tidak rantasa. Masyarakat Makassar khususnya di kecamatan Mariso sangat mengapresiasi dan mendukung adanya program Makassar tidak rantasa. Meskipun dari hasil pengamatan di lapangan dengan wawancara dengan sejumlah masyarakat masih ada yang belum tahu atau tidak peduli dengan program tersebut.

Partisipasi masyarakat juga terwujud melalui adanya kerjasama dan kekompakan untuk menciptakan lorong-lorong yang memiliki nama yang unik dan khas seperti, lorong Sehat, lorong KB (Keluarga Berencana) dan lorong Garden. Lorong-lorong tersebut sengaja diberikan nama yang unik dan memiliki pesan 
positif untuk selalu mengingatkan masyarakat tentang harapan yang hendak dicapai melalui program tersebut. Selain daripada itu kehadiran nama lorong tersebut juga sebagai penanda partisipasi masyarakat yang melibatkan lembaga lain, yakni dengan melakukan hubungan kerjasama. Seperti Lorong Sehat sebagai penanda lorong yang bekerjasama dengan Dinas Kesehatan, Lorong KB bekerjasama dengan BKKBN, sedangkan Lorong Garden adalah lorong binaan masyarakat setempat.

\section{PENUTUP}

Modal sosial masyarakat terlihat melalui partisipasi yang tinggi dari masyarakat yang dibuktikan dengan kegiatan kerja bakti atau bergotong royong secara bersamasama dalam menata dan menjaga kebersihan di Keamatan Mariso. Kegiatan gotong royong tersebut secara rutin dilaksanakan baik itu karena adanya perintah lansung dari pihak kecamatan atau agen pembaharu namun juga kegiatan gotong royong dilaksanakan atas dasar inisiatif warga setempat. Selanjutnya Masyarakat Mariso memiliki nilai-nilai yang masih tertanam diantara warganya tentang nilai sipakau (saling memanusiakan), sipakalebbi (saling menghargai), sipakainge (saling mengingatkan). Melalui nilai tersebut maka antara masyarakat dan masyarakat lainnya senantiasa terbangun rasa kemanusiaan, kesaling menghargai dan mengingatkan kepada suatu hal yang positif. Begitupun dengan pemerintah setempat dan masyarakat juga terbangun komunikasi yang berlandaskan atas nilai-nilai tersebut.

\section{DAFTAR PUSTAKA}

Aldrich, Daniel P. (2015). Social Capital and Community Resilience, 59 (2) 254-269.

Chang, Wen-Chun. (2009). Social capital and subjective happiness in Taiwan. International Journal of Social Economics,. 36 (8), 844-868.

Field, John. (2014). Modal Sosial. Bantul: Kreasi Wacana.

Fukuyama, Francis. (2004). The End Of History And The Last Man. Yogyakarta: Qalam.

Hanafi, Abdullah. (1986). Memasyarakatkan Ide-Ide Baru. Surabaya: Usaha Nasional.

Hasbullah, Jousairi. (2006). Sosial Capital (Menuju Keunggulan Budaya Manusia Indonesia). Jakarta: MR United Press.

Maulana. (2009). Pemanfaatan Modal Sosial Masyarakat Pada Program Pembangunan Gampong (PPG) Kecamatan Baktiya Barat Kabupaten Aceb Utara. Tesis Universitas Sumatra Utara.

Monika, Murzyn Kupisz. (2013). Cultural heritage in building and enhancing social capital. Journal of Cultural Heritage Management and Sustainable Development. 3 (1), 35-54.

Oxoby, Robert. (2009). Understanding socialinclusion, social cohesion, andsocial capital. International Journal of Social Economics, 36 (12), 1133-1152. 
Putnam. (2001). Bowling Alone: the Collapse and Revival of American Community, dalam Roy, Van Alison.

Scheiber, Laura Ann. (2014). Social capital and the target population. Social Enterprise Journal, 10 (2), 121-134.

Shen, Yuying. (2015). A literature analysis of social capital's transnational diffusion in Chinese sociology. Norfolk State University, USA Current Sociology. 1-18.

Sukmadinata, Nana Syaodih. (2007). Metode Penelitian Pendidikan. Bandung: Remaja Rosda Karya. 